\title{
Molecular Architecture and Symmetry Properties of 1,3-Alternate Calix[4]arenes with Orientable Groups at the Para Position of the Phenolic Rings
}

\author{
Lucio Toma, ${ }^{* \dagger}$ Laura Legnani, ${ }^{\dagger}$ Federica Compostella, ${ }^{\ddagger}$ Marta Giuliani, ${ }^{\S}$ Federica Faroldi, ${ }^{\S}$ \\ Alessandro Casnati, ${ }^{\S}$ and Francesco Sansone ${ }^{*, \S}$ \\ ${ }^{\dagger}$ Dipartimento di Chimica, Università di Pavia, Via Taramelli 12, 27100 Pavia, Italy \\ ${ }^{\ddagger}$ Dipartimento di Biotecnologie Mediche e Medicina Traslazionale, Università di Milano, Via Saldini 50, 20133 Milano, Italy \\ ${ }^{\S}$ Dipartimento di Chimica, Università di Parma, Parco Area delle Scienze 17/A, 43124 Parma, Italy
}
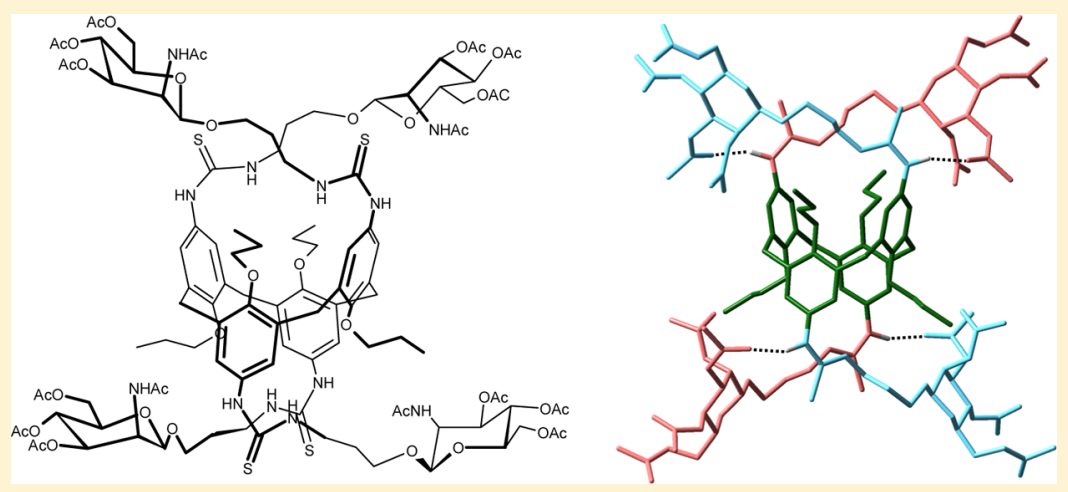

ABSTRACT: Two glycoclusters constituted by four fully acetylated $\beta$-acetylmannosamine residues linked through trimethylenethioureido spacers to a calix[4]arene core and differing for the presence of methoxy or propoxy groups at the lower rim were synthesized. One of the two compounds is fixed in the 1,3-alternate geometry by the presence of the propoxy groups, while the other is potentially free to assume one of the different geometries allowed in calix[4]arene. Their similar NMR spectra in chloroform clearly suggest the same 1,3-alternate geometry. Both compounds were submitted to a conformational investigation with the DFT approach at the standard B3LYP/6-31G(d) level. The two glycocalixarenes showed a large conformational preference for the same geometry that put the mannosamine moiety of one substituent close to the thioureido group of the opposite substituent. This allows the formation of intramolecular hydrogen bonds and originates a series of throughspace close contacts. A comparison with the NOESY maps evidence an excellent correspondence between experimental and theoretical data, thus giving an experimental validation of the highly symmetrical conformation that the two glycocalixarenes assume in apolar solvents.

\section{INTRODUCTION}

Calix[4]arenes, the smallest members of the calixarene family, have the lowest conformational mobility inside the class. Stable conformational isomers, which allow a controlled display of the substituents at the upper rim, are possible in the presence of alkyl groups larger than ethyl at the lower rim. In these cases the macrocycle is locked in specific structures differing in the orientation of the phenyl groups and named as cone, partial cone, 1,3-alternate, and 1,2-alternate. ${ }^{1}$

In the 1,3-alternate conformation the four aryl groups are alternatively up and down oriented, giving rise, in a derivative with the same functionalization on all the four rings, to a geometry with a very high degree of symmetry that makes very limited the number of nonequivalent hydrogen atoms in the structure. For example, the four methylene groups linking the aryl groups are all equivalent, so that the eight methylene hydrogens give rise to a unique observable singlet signal in the ${ }^{1} \mathrm{H}$ NMR spectra. However, though indistinguishable in an achiral environment, one couple of methylenes is enantiotopic with respect to the other one, and in a chiral environment they become diastereotopic and hence in principle distinguishable. The same occurs if chiral elements are linked to the calix[4]arene upper or lower rim. In this case in any environment two distinct signals could be observed in the ${ }^{1} \mathrm{H}$ NMR spectra for the above-mentioned methylene hydrogens, even when the chiral elements linked to the calixarene rim, all equivalent for symmetry, give rise to a unique set of signals.

In recent years, a large number of calixarenes with chiral glycosyl moieties linked at the upper rim have been reported. ${ }^{2}$

Received: July 26, 2016

Published: September 21, 2016 


\section{Chart 1}
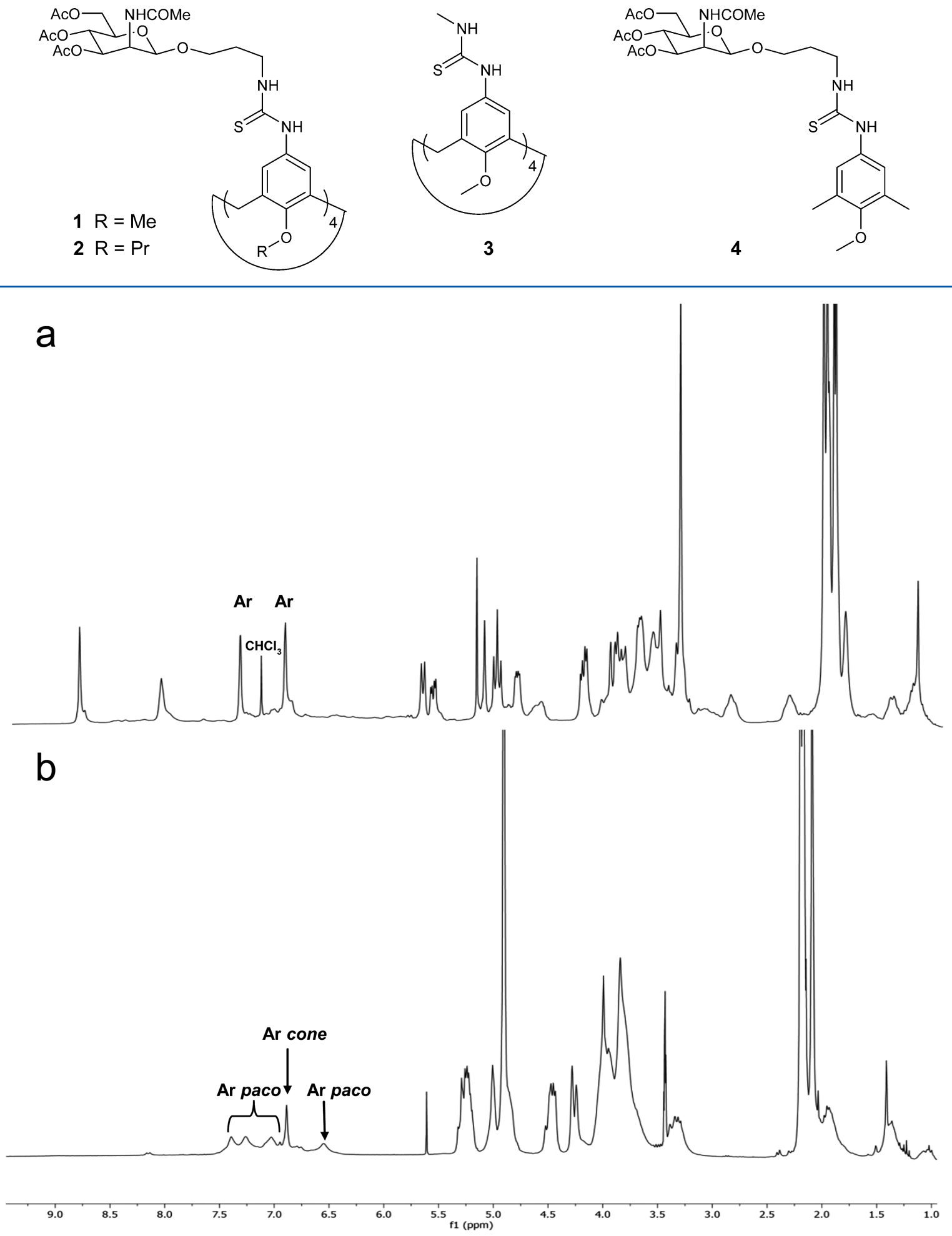

Figure 1. ${ }^{1} \mathrm{H}$ NMR spectra $(400 \mathrm{MHz}, 295 \mathrm{~K})$ of glycocalixarene 1: (a) in $\mathrm{CDCl}_{3}$ and (b) in $\mathrm{CD}_{3} \mathrm{OD}$.

Among them, different glycoclusters in which glycans are linked as $\beta$ anomers to the calixarene aromatic rings via a thioureido linker have been synthesized. Some of them are representative examples of the 1,3-alternate geometry. ${ }^{3}$ Recently, for instance, we synthesized the two thioureidocalix[4]arenes $\mathbf{1}$ and $\mathbf{2}$ containing four protected $\beta$-2-acetamido-2-deoxymannopyranoside chiral moieties at the upper rim and differing for the presence of methoxy or propoxy groups at the lower one (Chart 1). They were prepared as useful intermediates in an ongoing project aimed at obtaining their corresponding unprotected derivatives identified as potential multivalent ligands for proteins able to selectively recognize the given sugar in the context of biologically and medically relevant processes. In particular, $\mathrm{N}$-acetylmannosamine is a key element 


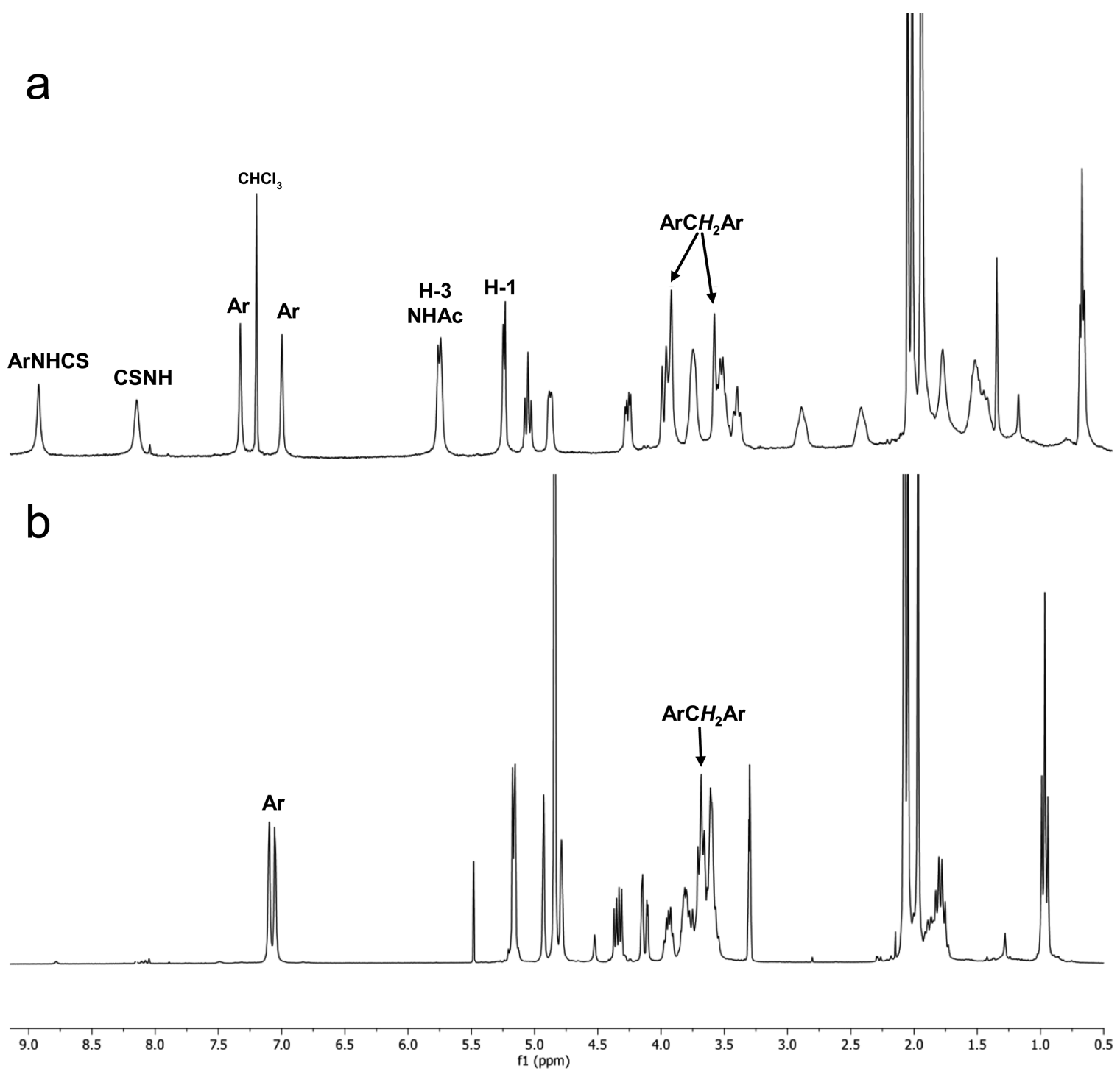

Figure 2. ${ }^{1} \mathrm{H}$ NMR spectrum $\left(400 \mathrm{MHz}, 295 \mathrm{~K}\right.$ ) of glycocalixarene 2: (a) in $\mathrm{CDCl}_{3}$ and (b) in $\mathrm{CD}_{3} \mathrm{OD}$.

in the structure of capsular polysaccharides (CPS), the virulence factor of harmful bacteria. ${ }^{4-7}$ Neoglycoconjugates displaying multiple copies of CPS fragments are useful probes to study the mechanism of the immunological activation, which is ruled by the multivalent interaction between the CPS of pathogenic bacteria and the proteins of the immune system. ${ }^{8}$ In this context, our compounds $\mathbf{1}$ and $\mathbf{2}$, when deprotected, will be tested within studies toward the development of synthetic vaccines.

Compound $\mathbf{2}$ is in the fixed 1,3-alternate geometry due to the presence of the propoxy groups and the experimental conditions used in the alkylation step of the calix[4]arene, whereas compound $\mathbf{1}$ is not locked in any specific conformation because of the small methyl groups that allow rotation of the phenyl rings through the annulus of the macrocycle.

Their ${ }^{1} \mathrm{H}$ NMR spectra presented some peculiarities that prompted us to investigate the conformational arrangement of the macrocycles and their glycoside substituents. A modeling study was performed on $\mathbf{1}$ and $\mathbf{2}$ through calculations at the standard B3LYP/6-31G(d) level, ${ }^{9,10}$ which has been successfully used in a previous study focused on two mannosylthioureido cone-calix[4] arenes, ${ }^{11}$ as their big molecular size did not allow higher theory levels. Before starting the modeling of the entire molecules, we investigated the conformational preferences of the 1,3-alternate thioureidocalix[4] arene core, i.e., compound 3 which is devoid of any glycosyl group, as well as those of compound 4 which can be considered the monomeric component of calixarenes $\mathbf{1}$ and 2. Finally, the modeling of the entire macrocycles, complete of the $\mathrm{N}$-acetylmannosamine moieties, was performed and the predicted properties compared with the NMR data.

\section{RESULTS AND DISCUSSION}

Synthesis and ${ }^{1} \mathrm{H}$ NMR Characterization. The glycocalix[4] arenes $\mathbf{1}$ and $\mathbf{2}$ were synthesized from the corresponding isothiocyanate precursors by reaction with 3-aminopropyl 2acetamido-3,4,6-tri- $O$-acetyl-2-deoxy- $\beta$-D-mannopyranoside.

The ${ }^{1} \mathrm{H}$ NMR spectrum of 1 indicates that in $\mathrm{CDCl}_{3}$ (Figure 1a) the calixarene is mainly present in one conformation. On the basis of strong similarities with the spectrum of $\mathbf{2}$ in the same solvent, described below (Figure 2a), it should be the 1,3alternate one. There is an unexpectedly large $\Delta \delta(0.42 \mathrm{ppm})$ between the two signals at 7.44 and $7.02 \mathrm{ppm}$, relative to the 8 aromatic protons, that are correlated as determined with COSY 


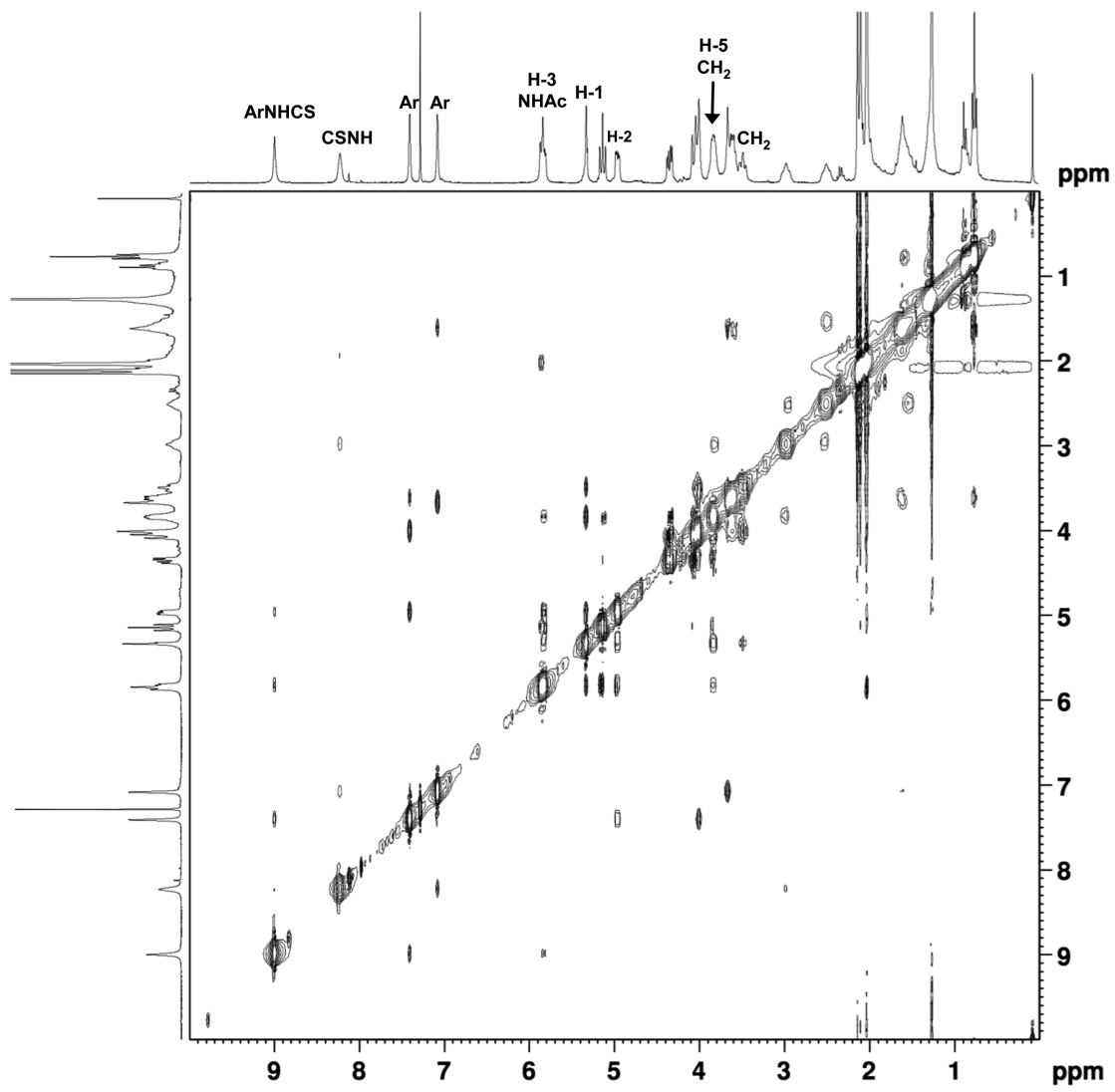

Figure 3. NOESY spectrum of glycocalixarene $2\left(300 \mathrm{MHz}, \mathrm{CDCl}_{3}, 295 \mathrm{~K}\right)$.

experiments. This means that all the phenolic units are equivalent but, at the same time, the two aromatic protons on each of them experience a different environment. Actually, previously reported tetraglycosyl thioureidocalix[4]arenes ${ }^{12}$ showed two different signals for the aromatic protons but almost completely overlapped or with a $\Delta \delta$ value around 0.1 ppm. In $\mathrm{CD}_{3} \mathrm{OD}$ (Figure $1 \mathrm{~b}$ ) the signals are rather broad but, from the pattern of those relative to the aromatic hydrogens (7.5-6.5 ppm), it is possible to conclude that the compound is mainly present as two species, the cone (signal at $6.89 \mathrm{ppm}$ ) and the partial cone (paco, signals at 7.39, 7.26, 7.03, and 6.55 ppm) conformations. Reasonably, the largely predominant conformation in $\mathrm{CDCl}_{3}$ is then stabilized by intramolecular hydrogen bonds that instead are broken by the polar solvent.

Being blocked in the 1,3-alternate conformation, a more detailed analysis can be done on the NMR spectra of $\mathbf{2}$ and in particular on their unexpected elements, shared with the spectra of $\mathbf{1}$. As observed for $\mathbf{1}$, in $\mathrm{CDCl}_{3}$ (Figure 2a) the aromatic protons of 2 give rise to two signals (7.38 and $7.05 \mathrm{ppm}$ ), each one corresponding to 4 protons and with a small $J$ value caused by a meta coupling confirmed by the correlation identified by COSY experiments. The $\Delta \delta$ is rather large also in this case $(0.33 \mathrm{ppm})$, and the difference between the two positions ortho with respect to the thiourea is evidenced also in the ${ }^{13} \mathrm{C} N M R$ where two different signals, at 128.6 and $128.4 \mathrm{ppm}$, are present for the corresponding carbon atoms. The two protons of each $\mathrm{CH}_{2}$ group of the propyl spacer between the sugar and the thiourea give two signals strongly split, at ca. 4 and at $3.46 \mathrm{ppm}$ for $\mathrm{OCH}_{2}$, at 3.80 and $2.95 \mathrm{ppm}$ for $\mathrm{CH}_{2} \mathrm{~N}$, at 2.48 and ca. 1.5 ppm for $\mathrm{CH}_{2} \mathrm{CH}_{2} \mathrm{CH}_{2}$. However, the most surprising is the presence of two well distinct singlets at 3.98 and $3.64 \mathrm{ppm}$ for the protons of the macrocycle methylene bridges instead of the single singlet typical of a calix[4] arene in this geometry and with the same substituents for all four phenolic rings. The unusual splitting is maintained also in the ${ }^{13} \mathrm{C}$ NMR spectrum with two signals at 38.2 and $36.6 \mathrm{ppm}$ for the carbon atoms of the calixarene bridges. As expected, the COSY spectrum does not indicate correlation between the two ${ }^{1} \mathrm{H}$ signals, each relative to four hydrogens, and this means that the two hydrogens linked to the same carbon atom are equivalent but the methylene groups are equal only two by two. This situation can originate only from the substituents at the upper rim because of the presence of both chiral glycoside units and donor/acceptor groups potentially involved in hydrogen bonding. In particular, the hydrogen-bond network is relevant since by recording the ${ }^{1} \mathrm{H}$ NMR spectrum in $\mathrm{CD}_{3} \mathrm{OD}$, solvent able to break these interactions, the protons of the methylene bridges give rise only to one singlet at around $3.7 \mathrm{ppm}$. In addition, in this solvent, the aromatic protons are more similar, with their signals being closer (7.10 and $7.05 \mathrm{ppm})$, as observed for other calixarenes functionalized at the upper rim with thiourea groups, and the splitting between the hydrogen atoms of each spacer methylene group disappears (Figure 2b).

NOESY experiments were performed with 2 changing the mixing time value ( $\mathrm{d} 8$ ) from 0.2 to $0.6 \mathrm{~ms}$, but no significant variations were found in the three collected two-dimensional spectra. Analyzing the two-dimensional map obtained with $\mathrm{d} 8=$ $0.2 \mathrm{~ms}$ (Figure 3), we can in particular observe that each $\mathrm{NH}$ proton of the thiourea correlate with only one of the aromatic protons. This suggests that thiourea is in the $E Z$ conformation and is not rotating around the bond between $\mathrm{NH}$ and phenyl. Moreover, there is a correlation between mannosamine $\mathrm{H}-2$ and the aromatic proton already correlating with the hydrogen of the thioureido $\mathrm{NH}$ directly attached to the aromatic ring of 
a

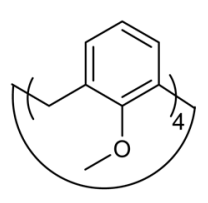

b
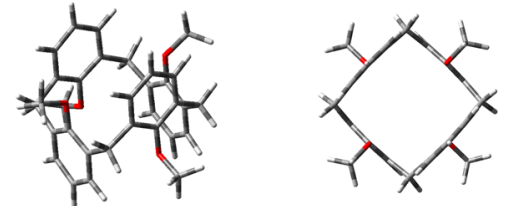
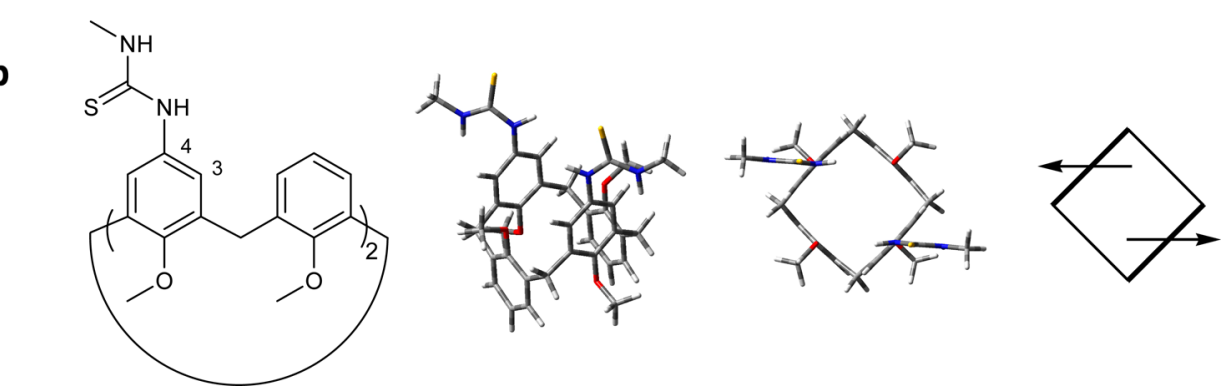

Figure 4. (a) Unsubstituted calix[4]arene in the 1,3-alternate geometry: chemical structure, 3D plot in the side and top view, schematic representation. (b) Calix[4]arene in the 1,3-alternate geometry with two methylthioureido groups: chemical structure, 3D plot in the side and top view, schematic representation.

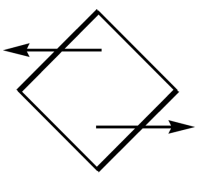

A

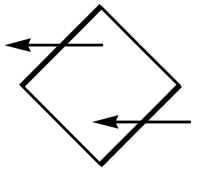

B

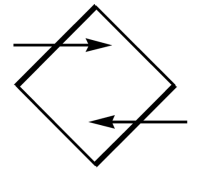

C

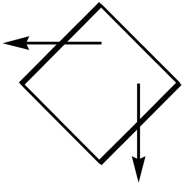

D

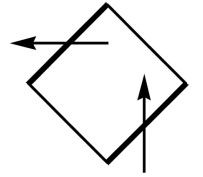

E

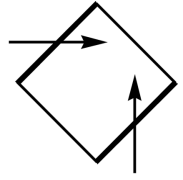

$\mathbf{F}$

Figure 5. Schematic representation of the possible relative orientations of two thioureido groups at the top side of a calix[4] arene in the 1,3-alternate conformation.

the calixarene scaffold. Other noteworthy correlations are that between the same thioureido $\mathrm{NH}$ atom and the signal at 5.80 ppm, where H-3 and NHAc are overlapped, and, although weaker, that with $\mathrm{H}-2$. Cross peaks are also present between $\mathrm{H}$ 1 and the $\mathrm{CH}_{2}$ nearby to the anomeric oxygen and between $\mathrm{H}$ 1 and the $\mathrm{CH}_{2}$ adjacent to the thiourea or H-5 (overlapped signals in this case). However, the latter correlation is expected since $\mathrm{H}-1$ and $\mathrm{H}-5$ are both axial, pointing in the $\alpha$ face.

Modeling of the 1,3-Alternate Thioureidocalix[4]arene Core. The restricted rotation of the pseudoamide $\mathrm{NH}-\mathrm{C}=\mathrm{S}$ bonds of the thioureido units and the consequent tendency to planarity allows the existence of four geometrical isomers, named $Z Z, Z E, E Z$, and $E E$. When the almost planar thioureido unit is linked to the planar phenyl ring, overall coplanarity is not allowed, due to the steric hindrance of either the thiocarbonyl sulfur atom or the $\mathrm{NH}$ groups with the aromatic hydrogen atoms ortho to the thioureido group. The preferred angle between the thioureido and the phenyl planes is about $45^{\circ}$, and this makes possible a number of different relative orientations. The examination of the geometries of an unsubstituted calixarene in the 1,3-alternate conformation (Figure 4a) shows that it has a cavity that, when observed from a top view, looks like a square and can be schematically represented using such geometrical shape. In the 1,3-alternate thioureidocalix[4]arene 3 (Chart 1), for example, two thioureido groups are at the top of the calix and two at the bottom. If we consider only those at the top (Figure $4 \mathrm{~b}$ ) and depict them as arrows that are inclined by $45^{\circ}$ to the sides of the square $\left(\tau_{\mathrm{CS}-\mathrm{NH}-\mathrm{C} 4-\mathrm{C} 3} \approx 45^{\circ}\right)$, a schematic representation such as that in Figure $4 \mathrm{~b}$ can be drawn. This representation is one of the six different arrangements possible for the two arrows, all shown in Figure 5. The combination of these arrow arrangements with the four geometrical isomers of thioureido allows the existence of a number of different geometries.

Thus, the conformational preferences of the 1,3-alternate thioureidocalix[4]arene core, i.e., the structure devoid of any glycosyl group, were investigated on the model compound 3 in which each thioureido group bears just a methyl group. The starting geometries deriving from the six $\mathbf{A}-\mathbf{F}$ orientations combined with each type of thiouredo geometry were fully optimized in vacuum at the B3LYP/6-31G(d) level. As it can be seen in Table 1, the EZ geometry is largely preferred by compound 3 with all other conformational isomers of thioureido being less stable by more than $10 \mathrm{kcal} / \mathrm{mol}$. The preferred relative orientation of the thioureido groups is the one indicated as $\mathbf{C}$ in Figure 5 followed by the $\mathbf{B}$ conformer,

Table 1. Relative Energy ( $\mathrm{kcal} / \mathrm{mol}$ ) and Population Percentage at $298 \mathrm{~K}$ (\%) of Conformers of Compound 3 Optimized at the B3LYP/6-31G(d) Level of Theory

$\begin{array}{lcc}\text { conf. }^{a} & E_{\text {rel }} & \% \\ \text { 3A-EZ } & 6.14 & 0.0 \\ \text { 3B-EZ } & 2.36 & 1.8 \\ \text { 3C-EZ } & 0.00 & 98.1 \\ \text { 3D-EZ } & 6.89 & 0.0 \\ \text { 3E-EZ } & 4.02 & 0.1 \\ \text { 3F-EZ } & 9.39 & 0.0 \\ \text { 3C-ZE } & 10.42 & 0.0 \\ \text { 3E-ZZ } & 10.59 & 0.0 \\ \text { 3A-EE } & 11.89 & 0.0\end{array}$

${ }^{a}$ The data of all six $E Z$ conformers and those of the best $Z E, Z Z$, and $E E$ conformers are reported. 


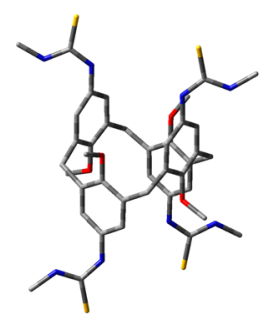

3A-EZ

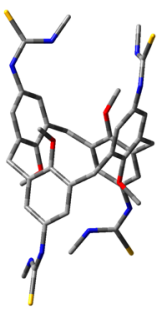

$3 \mathbf{F}-E Z$

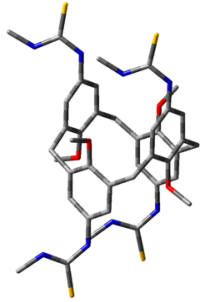

3B-EZ

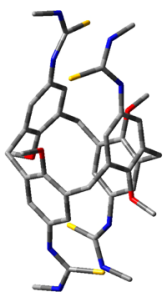

3C-ZE

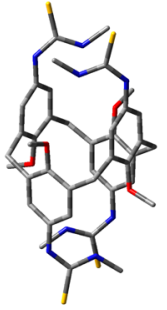

3C-EZ

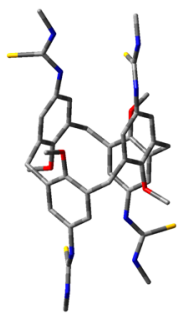

$3 E-Z Z$

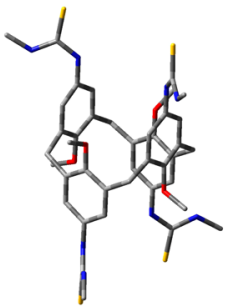

3D-EZ

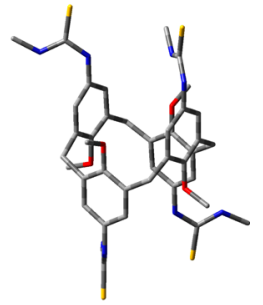

$3 \mathrm{E}-E Z$

Figure 6. Three-dimensional plot of conformers $3 \mathbf{A}-\mathbf{F}$ of compound 3 in the $E Z$ geometry and the preferred conformers in the $Z E, Z Z$, and $E E$ geometries. Hydrogen atoms are omitted for clarity.

less stable by more than $2 \mathrm{kcal} / \mathrm{mol}$, and by the other conformers, E, A, D, and F.

Figure 6 reports the three-dimensional plots of the six conformers of compound 3 in the EZ geometry together with the preferred conformer for each of the other thiouredo geometries. The global minimum $3 \mathrm{C}-\mathrm{EZ}$ is a highly symmetric structure in which couples of parallel thioureido groups are involved in weak hydrogen bonds with the methoxy oxygen atoms $(\mathrm{N}-\mathrm{H} \cdots \mathrm{O}$ distance $2.93 \AA)$ and lock the top and the bottom of the cavity. The planes of the thioureido groups are parallel also in the second minimum 3B-EZ and in the less stable 3A-EZ. All geometries with orthogonal thioureido planes are much less stable than the global minimum 3C-EZ.

Modeling of the Model Compound 4. The conformational behavior of the monomeric model $\beta$-2-acetamido-2deoxy-D-mannosylthiourea 4 (Chart 1) was then investigated. First, attention was focused on the degrees of conformational freedom deriving from the four geometrical isomers of the thiourea and maintaining the trimethylene chain in the extended all-trans geometry and the glycosidic bond in the orientation suggested by the exo-anomeric effect. The corresponding four starting geometries were built and optimized as above for 3 . As expected, a neat preference was observed for the EZ thiourea geometry (Table 2 and Figure 7, conformer 4A-EZ) that was preferred over the other three geometries by more than $4 \mathrm{kcal} / \mathrm{mol}$.

Taking into account only the favorite EZ geometry, all possible orientations at the single bonds of the chain connecting mannosammine to the thioureido group and characterized by the torsional angles $\tau_{1}-\tau_{5}$ were considered. As expected, no more stable orientation at the glycosidic bond (defined by $\tau_{1}$ ) was found, whereas several combinations of torsions at the other single bonds (defined by $\tau_{2}-\tau_{5}$ ), different by the all-trans geometry characterizing $4 \mathrm{~A}-\mathrm{EZ}$, were more stable. In particular, the global minimum $4 \mathrm{~B}-E Z$ was shown to be $1.83 \mathrm{kcal} / \mathrm{mol}$ more stable than $4 \mathrm{~A}-E Z$. The data of all conformers are reported in Table 2 and their three-dimensional plots in Figure 7 that show the great variability in the folds allowed to the trimethylene chain.
Table 2. Relative Energy ( $\mathrm{kcal} / \mathrm{mol}$ ) and Selected Torsional Angles (degrees) ${ }^{a}$ of Conformers of Compound 4 Optimized at the B3LYP/6-31G(d) Level of Theory

\begin{tabular}{|c|c|c|c|c|c|c|}
\hline conf. & $E_{\text {rel }}$ & $\tau_{1}$ & $\tau_{2}$ & $\tau_{3}$ & $\tau_{4}$ & $\tau_{5}$ \\
\hline 4A-EZ & 1.83 & -67 & -173 & -178 & 180 & 173 \\
\hline 4A-EE & 5.82 & -68 & -174 & -178 & 179 & 136 \\
\hline 4A- $Z Z$ & 6.57 & -67 & -172 & -177 & -179 & 177 \\
\hline 4A-ZE & 6.75 & -68 & -176 & 180 & 119 & 172 \\
\hline 4B-EZ & 0.00 & -68 & -169 & 64 & 180 & -83 \\
\hline 4C-EZ & 0.76 & -66 & 170 & -62 & 177 & -149 \\
\hline 4D-EZ & 0.97 & -72 & 179 & 176 & -69 & 106 \\
\hline 4E-EZ & 1.03 & -76 & -90 & -60 & 178 & 84 \\
\hline $4 \mathbf{F}-E Z$ & 1.13 & -68 & -176 & -172 & 67 & -162 \\
\hline 4G- $E Z$ & 1.34 & -68 & -175 & 178 & 179 & -87 \\
\hline $4 \mathbf{H}-E Z$ & 1.64 & -69 & -176 & -178 & -179 & 88 \\
\hline
\end{tabular}

Modeling of the Calixarenes 1 and 2. The complete structures of the mannosylthioureidocalix[4] arene $\mathbf{1}$ and $\mathbf{2}$ in the 1,3-alternate conformation were then built on the basis of the conformational preferences of the thioureidocalix[4] arene core 3 and the model compound 4 . In the ${ }^{1} \mathrm{H}$ NMR spectra of 1 and 2, recorded in $\mathrm{CDCl}_{3}$, all four groups linked to the para position of each phenolic ring are equivalent and give rise to a unique set of signals; similarly, only one singlet is observed for the four methoxy methyl groups of $\mathbf{1}$ and one set of signals for the propoxy hydrogen atoms of $\mathbf{2}$ (see above). These NMR experimental data are consistent with the structures derived either from the preferred conformer of 3, 3C-EZ or from the much less stable conformer $3 \mathrm{~A}-\mathrm{EZ}$, whose symmetry properties make equivalent the four alkoxy groups and the four substituted thioureas. Furthermore, for particular folds of the linker, the geometries of $\mathbf{1}$ and 2 built from $3 C-E Z$ put the mannosammine moiety of one substituent close to the thioureido group of the opposite substituent. Conversely, all the geometries built from 3A-EZ put the glycosyl moieties away. Thus, the $3 \mathrm{~A}-E Z$ geometries were discarded not only for 


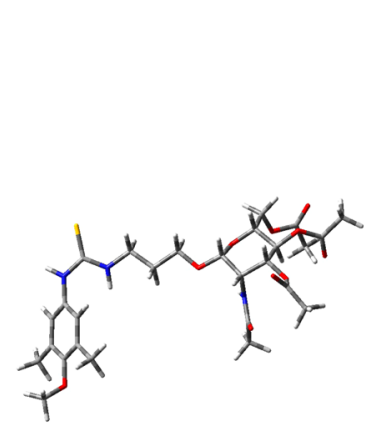

4A-EZ

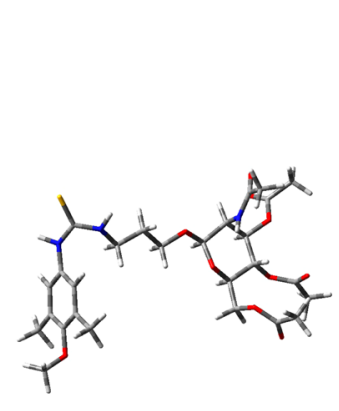

4A-EE

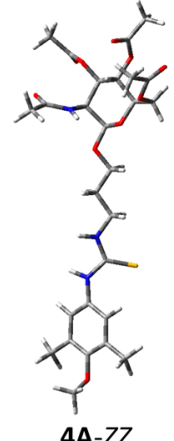

4A-ZZ

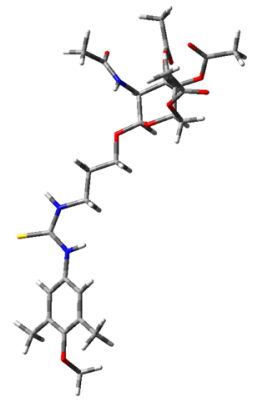

4A-ZE

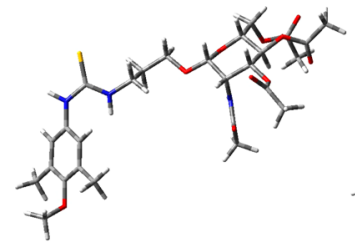

4B-EZ

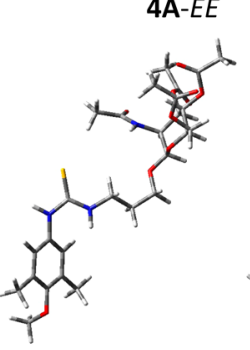

4C-EZ

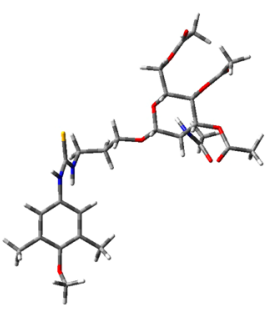

4D-EZ

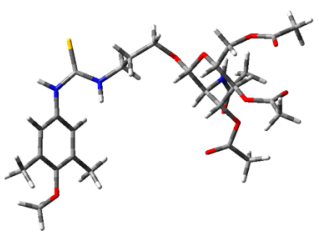

4E-EZ

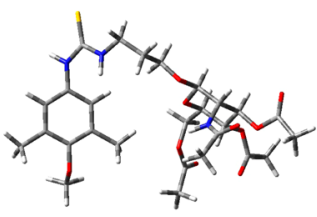

4F-EZ

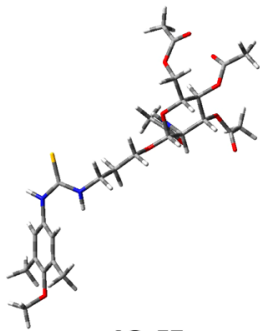

4G-EZ

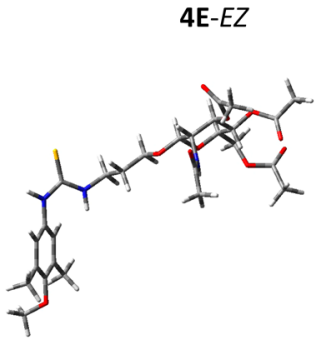

4H-EZ

Figure 7. Three-dimensional plot of conformers of compound 4.

energetic but also for geometrical reasons, as the NOESY experiments performed on $\mathbf{2}$ indicate a spatial proximity between thioureido and mannosamine hydrogen atoms. The numerous starting geometries of 1 and 2 , built up by connecting 3C-EZ to mannosamine through each of the different folds allowed for the linker in model compound 4, were submitted to optimization.

First, calculations were performed on $\mathbf{1}$, and large differences were found in the stability of its various conformers. The global minimum $1 \mathbf{A}$ and the two next minima $\mathbf{1 B}$ and $\mathbf{1 C}$, less stable than $1 \mathrm{~A}$ by 6.42 and $7.18 \mathrm{kcal} / \mathrm{mol}$, respectively, are described in Table 3. In $\mathbf{~ A ~ t h e ~ l i n k e r ~ a s s u m e s ~ t h e ~ s a m e ~ f o l d ~ p r e d i c t e d ~ a s ~}$ the most stable for the monomeric model $4,4 \mathrm{~B}-E Z$, whereas

Table 3. Relative Energy ( $\mathrm{kcal} / \mathrm{mol}$ ) and Selected Torsional Angles (degrees) ${ }^{a}$ of Conformers of Glycocalixarenes 1 and 2 Optimized at the B3LYP/6-31G(d) Level of theory

\begin{tabular}{cccccccl} 
conf. & $E_{\text {rel }}$ & $\tau_{1}$ & \multicolumn{1}{c}{$\tau_{2}$} & \multicolumn{1}{c}{$\tau_{3}$} & \multicolumn{1}{c}{$\tau_{4}$} & \multicolumn{1}{c}{$\tau_{5}$} & $\tau_{6}$ \\
\hline 1A & 0.00 & -70 & -141 & 68 & -172 & -85 & 119 \\
1B & 6.42 & -85 & -88 & -55 & -174 & 86 & 52 \\
1C & 7.18 & -82 & -103 & -68 & 172 & 82 & 139 \\
2A & 0.00 & -70 & -140 & 67 & -173 & -85 & 121 \\
2B & 9.36 & -86 & -89 & -55 & -173 & 88 & 50 \\
2C & 8.90 & -79 & -101 & -70 & 173 & 83 & 140
\end{tabular}

${ }^{a} \tau_{1}: \mathrm{O}-\mathrm{C}-\mathrm{O}-\mathrm{CH}_{2} \cdot \tau_{2}: \mathrm{C}-\mathrm{O}-\mathrm{CH}_{2}-\mathrm{CH}_{2} \cdot \tau_{3}: \mathrm{O}-\mathrm{CH}_{2}-\mathrm{CH}_{2}-\mathrm{CH}_{2}$. $\tau_{4}: \mathrm{CH}_{2}-\mathrm{CH}_{2}-\mathrm{CH}_{2}-\mathrm{NH} . \tau_{5}: \mathrm{CH}_{2}-\mathrm{CH}_{2}-\mathrm{NH}-\mathrm{CS} . \tau_{6}: \mathrm{CS}-\mathrm{NH}-\mathrm{C} 4-$ $\mathrm{C} 3$. both $1 \mathrm{~B}$ and $1 \mathrm{C}$ show the same fold predicted for $4 \mathrm{E}-\mathrm{EZ}$. In all three structures the overall geometry is stabilized by a hydrogen bond; in 1A and 1C it involves the thioureido $\mathrm{NH}$ hydrogen atom close to the aromatic ring, which acts as donor, and the acetyl carbonyl oxygen at position 3 of mannosamine, acting as acceptor. In $1 \mathrm{~B}$ the same $\mathrm{NH}$ hydrogen atom makes a $\mathrm{H}$ bond with the acetamido carbonyl oxygen at position 2. This allows a close proximity of this hydrogen atom to both $\mathrm{H} 2$ and $\mathrm{H} 3$ (1A and $\mathbf{1 C}$ ) or only $\mathrm{H} 2$ (1B) of mannosamine. ${ }^{13}$

Starting from these three conformers of $\mathbf{1}$, the corresponding conformers of $\mathbf{2}$ were obtained by replacing each methoxy with propoxy group. In propoxy, the $\mathrm{O}-\mathrm{CH}_{2}$ and the $\mathrm{CH}_{2}-\mathrm{CH}_{2}$ single bonds represent two more degrees of conformational freedom. All combinations of gauche and trans orientations at these bonds were evaluated showing in every case a neat preference for a defined fold. In Figure 8 are represented the three-dimensional plots of the conformers 2A, 2B, and 2C, whereas in Table 4 are reported all significant couples of hydrogen atoms that are at short distances $(<3 \AA)$ in the preferred 2A conformer. A comparison with the NOESY maps evidences the excellent correspondence between experimental and theoretical data also considering further significant correlations in addition to those previously described, such as those between $\mathrm{NH}_{\mathrm{CH} 2}$ and $\mathrm{SCNHCHH} H_{\text {pro-s }}$ or between $\mathrm{H} 1$ and $\mathrm{CH}_{2} \mathrm{CH}_{2} \mathrm{CHH}_{\text {pro- } \mathrm{O}} \mathrm{O}$ that both furnish a validation to the corresponding calculated distances. 


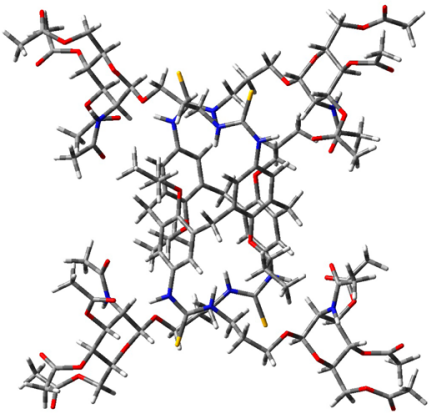

2A

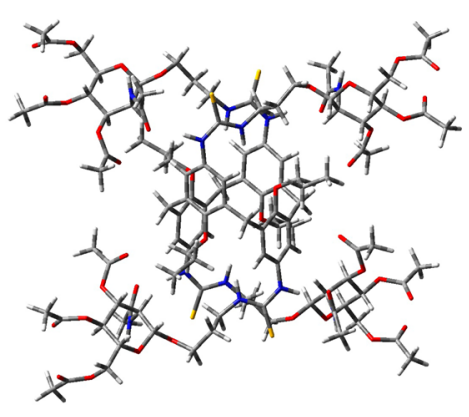

2B

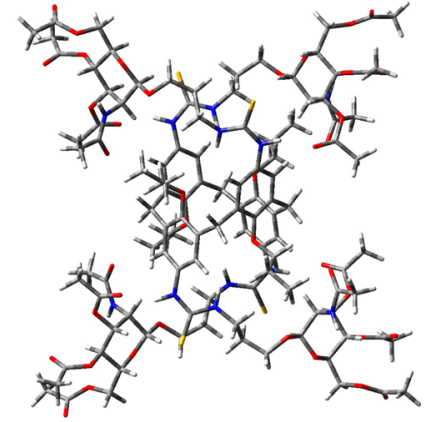

2C

Figure 8. Three-dimensional plots of the minimum energy conformers of compound 2.

Table 4. Short Hydrogen-Hydrogen Distances (Angstroms) in the Global Minimum Conformer $2 \mathrm{~A}$ of Compound 2

\begin{tabular}{|c|c|c|c|c|c|}
\hline $\mathrm{H}_{\mathrm{a}}$ & $\mathrm{H}_{\mathrm{b}}$ & $\mathrm{H}_{\mathrm{a}}-\mathrm{H}_{\mathrm{b}}$ distance & $\mathrm{H}_{\mathrm{a}}$ & $\mathrm{H}_{\mathrm{b}}$ & $\mathrm{H}_{\mathrm{a}}-\mathrm{H}_{\mathrm{b}}$ distance \\
\hline $\mathrm{NH}_{\mathrm{ar}}$ & $\mathrm{H}_{\text {ortho,a }}$ & 2.62 & $\mathrm{H} 3$ & H1 & 2.55 \\
\hline $\mathrm{NH}_{\mathrm{ar}}$ & $\mathrm{H} 3$ & 2.93 & $\mathrm{NHCO}$ & $\mathrm{H} 4$ & 2.63 \\
\hline $\mathrm{NH}_{\mathrm{ar}}$ & $\mathrm{H} 2$ & 2.74 & $\mathrm{H} 3$ & $\mathrm{H} 2$ & 2.42 \\
\hline $\mathrm{NH}_{\mathrm{CH} 2}$ & $\mathrm{H}_{\text {ortho,b }}$ & 2.27 & $\mathrm{H} 3$ & H5 & 2.66 \\
\hline $\mathrm{NH}_{\mathrm{CH} 2}$ & $\mathrm{SCNHCH} H_{\text {pro-S }}$ & 2.27 & $\mathrm{NHCO}$ & $\mathrm{COCH}_{3}$ & $2.77^{a}$ \\
\hline $\mathrm{H}_{\text {ortho,a }}$ & $\mathrm{H} 2$ & 2.51 & $\mathrm{H} 1$ & $\mathrm{H} 2$ & 2.50 \\
\hline $\mathrm{H}_{\text {ortho,a }}$ & $\mathrm{ArCH}_{\mathrm{a}} \mathrm{HAr}$ & 2.21 & H1 & H5 & 2.26 \\
\hline $\mathrm{H}_{\text {ortho,a }}$ & OCHHEt & 2.77 & $\mathrm{H} 1$ & $\mathrm{CH}_{2} \mathrm{CH}_{2} \mathrm{CH} H_{\text {pro-R }} \mathrm{O}$ & 2.23 \\
\hline $\mathrm{H}_{\text {ortho,b }}$ & $\mathrm{ArCH}_{\mathrm{b}} \mathrm{HAr}$ & 2.24 & $\mathrm{ArCH}_{\mathrm{a}} \mathrm{HAr}$ & OCHHEt & 2.06 \\
\hline $\mathrm{H}_{\text {ortho,b }}$ & $\mathrm{OCH}_{2} \mathrm{CHHMe}$ & 2.54 & & & \\
\hline
\end{tabular}

\section{CONCLUSIONS}

The intriguing ${ }^{1} \mathrm{H}$ NMR spectra of two glycosylthioureidocalix[4]arenes, showing some unexpected peculiarities and a large dependence of the signal pattern from the solvent, prompted us to investigate their conformational preferences through calculations at the $\mathrm{B} 3 \mathrm{LYP} / 6-31 \mathrm{G}(\mathrm{d})$ level. The two glycoclusters $\mathbf{1}$ and $\mathbf{2}$ are both constituted by fully acetylated $\beta$-acetylmannosamine residues linked to the calix[4]arene core through trimethylenethioureido spacers. Calixarene 2 is fixed in the 1,3-alternate geometry by the presence of propoxy groups at the lower rim. For macrocycle 1, though the methoxy groups at the lower rim make it potentially free to assume one of the four different geometries allowed to calix[4]arene, the NMR spectra in chloroform clearly suggest the same 1,3-alternate geometry as $\mathbf{2}$.

The modeling study was performed on $\mathbf{1}$ and $\mathbf{2}$ through stepwise investigation that started from a thorough investigation of the conformational properties of the calixarene core 3 and the model monomeric component 4 . When the entire macrocycles $\mathbf{1}$ and $\mathbf{2}$ were modeled, they both showed a large conformational preference for the same geometry stabilized by a series of intramolecular hydrogen bonds that put the glycosyl terminus of one arm close to the opposite aryl and thioureido moieties. This originates a series of through-space close contacts all experimentally confirmed by the NOESY maps.

The approach here described, which combines both theoretical and experimental methods, is shown to be a powerful tool in dealing with problems such as the solution of the three-dimensional structure of complex macrocycles, not easy to obtain in other ways.

\section{EXPERIMENTAL SECTION}

General Information. The reactions were carried out under nitrogen atmosphere using previously oven-dried glassware. Silica gel 60 (70-230 mesh) was used for flash chromatography. ${ }^{1} \mathrm{H}$ NMR and ${ }^{13} \mathrm{C}$ NMR spectra were recorded on 300 and 400 spectrometers (observation of ${ }^{1} \mathrm{H}$ nucleus at 300 and $400 \mathrm{MHz}$, respectively, and of ${ }^{13} \mathrm{C}$ nucleus at 75 and $100 \mathrm{MHz}$, respectively). All chemical shifts are reported in parts per million (ppm) using the residual peak of the deuterated solvents, whose values are referred to tetramethylsilane (TMS, $\delta_{\text {TMS }}=0$ ), as internal standard. ${ }^{13} \mathrm{C}$ NMR spectra were performed with proton decoupling. ${ }^{1} \mathrm{H}-{ }^{1} \mathrm{H}$ COSY and ${ }^{1} \mathrm{H}-{ }^{13} \mathrm{C}$ HSQC 2D NMR experiments were performed for complete assignment of the signals to the molecular structures. Electrospray ionization (ESI) mass analyses were performed with a LTQ Orbitrap $\mathrm{XL}$ spectrometer in positive ionization mode. Melting points were determined in capillaries sealed under nitrogen atmosphere.

5,11,17,23-Tetrakis [(aminopropyl-2-acetamido-3,4,6-tri-O-acetyl-2-deoxy- $\beta$-D-mannopiranosyl) thioureido]-25,26,27,28tetramethoxycalix[4]arene (1). In a two-neck round-bottom flask $5,11,17,23$-tetraisothiocyanate-25,26,27,28-tetramethoxy-calix[4] arene $(0.030 \mathrm{~g}, 0.042 \mathrm{mmol})$ was dissolved in $10 \mathrm{~mL}$ of dry $\mathrm{CH}_{2} \mathrm{Cl}_{2}$ under $\mathrm{N}_{2}$ atmosphere. Then 3-aminopropyl 2-acetamido-3,4,6-tri- $O$-acetyl-2deoxy- $\beta$-D-mannopyranoside $(0.086 \mathrm{~g}, 0.21 \mathrm{mmol})$ and $\mathrm{Et}_{3} \mathrm{~N}(0.18$ $\mathrm{mL}, 1.3 \mathrm{mmol}$ ) were added. The mixture was allowed to react at room temperature for $48 \mathrm{~h}$ (with addition of 0.5 equiv of sugar and base after 1 night). The reaction was quenched by removal of the solvent under reduced pressure. The pure compound was obtained with purification via flash column chromatography (eluent $\mathrm{CH}_{2} \mathrm{Cl}_{2}: \mathrm{MeOH} 20: 1 \mathrm{v}$ :v) as a brownish solid $(0.050 \mathrm{~g}, 0.021 \mathrm{mmol}, 50 \%$ yield). Mp: $136.6-138.2$. ${ }^{1} \mathrm{H}$ NMR $\left(300 \mathrm{MHz}, \mathrm{CDCl}_{3}\right)$ signals of the predominant conformation $\delta(\mathrm{ppm}): 8.91$ (s, 4H, ArNHCS), $8.16(\mathrm{~s}, 4 \mathrm{H}$, $\left.\mathrm{CSNHCH}_{2}\right), 7.44(\mathrm{~s}, 4 \mathrm{H}, \mathrm{ArH}), 7.02(\mathrm{~s}, 4 \mathrm{H}, \mathrm{ArH}), 5.76(\mathrm{~d}, 4 \mathrm{H}, J=$ $8.9 \mathrm{~Hz}, \mathrm{NHAc}), 5.67\left(\mathrm{dd}, 4 \mathrm{H}, J_{2,3}=3.9, J_{3,4}=9.9 \mathrm{~Hz}, \mathrm{H} 3\right), 5.19$ (br s, $4 \mathrm{H}, \mathrm{H} 1), 5.08(\mathrm{t}, 4 \mathrm{H}, J=10.0 \mathrm{~Hz}, \mathrm{H} 4), 4.92-4.88(\mathrm{~m}, 4 \mathrm{H}, \mathrm{H} 2), 4.28$ $\left(\mathrm{dd}, 4 \mathrm{H}, J_{6 \mathrm{a}, 5}=5.1, J_{6 \mathrm{a}, 6 \mathrm{~b}}=12.2 \mathrm{~Hz}, \mathrm{H}_{6 \mathrm{a}}\right), 4.03-3.80(\mathrm{~m}, 8 \mathrm{H}, \mathrm{H} 6 \mathrm{~b}$, $\mathrm{OCHHCH}_{2} \mathrm{CH}_{2}$ ), 4.01 (s, $4 \mathrm{H}, \mathrm{ArCH}_{2} \mathrm{Ar}$ ), 3.80-3.52 (m, 8H, H5, $\mathrm{CHHNH}), 3.62\left(\mathrm{~s}, 4 \mathrm{H}, \mathrm{ArCH} \mathrm{H}_{2} \mathrm{Ar}\right), 3.45-3.30$ (br, 4H, 
$\mathrm{OCHHCH}_{2} \mathrm{CH}_{2}$ ), 3.40 (s, 12H, $\mathrm{OCH}_{3}$ ), 2.94 (br, $\left.4 \mathrm{H}, \mathrm{CHHNH}\right), 2.39$ (br, $\left.4 \mathrm{H}, \mathrm{OCH}_{2} \mathrm{CHHCH}_{2}\right), 2.08\left(\mathrm{~s}, 12 \mathrm{H}, \mathrm{CH}_{3} \mathrm{CO}\right), 2.03(\mathrm{~s}, 12 \mathrm{H}$, $\mathrm{CH}_{3} \mathrm{CO}$ ); 1.98 (s, $\left.12 \mathrm{H}, \mathrm{CH}_{3} \mathrm{CO}\right), 1.96\left(\mathrm{~s}, 12 \mathrm{H}, \mathrm{CH}_{3} \mathrm{CO}\right), 1.45$ (br, $\left.4 \mathrm{H}, \mathrm{OCH}_{2} \mathrm{CHHCH}_{2}\right) .{ }^{13} \mathrm{C}\left\{{ }^{1} \mathrm{H}\right\}$ NMR $\left(75 \mathrm{MHz} \mathrm{CDCl}_{3}\right) \delta(\mathrm{ppm})$ : 181.7 (CS), 171.7, 171,5, 170.6, and $169.9\left(\mathrm{COCH}_{3}\right), 154.2$ (Ar ipso), 135.2 (Ar ortho), 134.0 (Ar para), 128.4 and 127.5 (ArH meta), 99.7 (C1), 74.1 (C3), 73.2 (C5), $67.4\left(\mathrm{OCH}_{2} \mathrm{CH}_{2} \mathrm{CH}_{2}\right), 66.1$ (C4); 62.6 (C6); $58.4\left(\mathrm{OCH}_{3}\right) ; 51.3(\mathrm{C} 2), 42.4\left(\mathrm{CH}_{2} \mathrm{NH}\right), 36.8$ and 35.2 $\left(\mathrm{ArCH} \mathrm{H}_{2} \mathrm{Ar}\right), 29.5\left(\mathrm{OCH}_{2} \mathrm{CH}_{2} \mathrm{CH}_{2}\right), 23.4$, 21.1, and $20.8\left(\mathrm{COCH}_{3}\right)$. HRMS (ESI-TOF) $m / z:[\mathrm{M}+2 \mathrm{Na}]^{2+}$ calcd for $\mathrm{C}_{104} \mathrm{H}_{140} \mathrm{~N}_{12} \mathrm{O}_{40} \mathrm{~S}_{4} \mathrm{Na}_{2}$ 1185.8996; found 1185.8978 .

5, 11,17,23-Tetrakis[(aminopropil-2-acetamido-3,4,6-tri-O-acetyl2-deoxy- $\beta$-D-mannopiranosyl) thioureido]-25,26,27,28tetrapropoxycalix[4]arene 1,3-Alternate (2). In a two-neck roundbottom flask 5,11,17,23-tetraisothiocyanate-25,26,27,28-tetrapropoxycalix [4] arene 1,3-alternate $(0.032 \mathrm{~g}, 0.039 \mathrm{mmol})$ was dissolved in 5 $\mathrm{mL}$ of dry $\mathrm{CH}_{2} \mathrm{Cl}_{2}$ under $\mathrm{N}_{2}$ atmosphere. Then 3-aminopropyl 2acetamido-3,4,6-tri- $O$-acetyl-2-deoxy- $\beta$-D-mannopyranoside $(0.079 \mathrm{~g}$, $0.20 \mathrm{mmol})$ and $\mathrm{Et}_{3} \mathrm{~N}(0.16 \mathrm{~mL}, 1.2 \mathrm{mmol})$ were added. The mixture was allowed to react at room temperature for $48 \mathrm{~h}$ (with addition of 0.5 equiv of sugar and base after 1 night). The reaction was quenched by removal of the solvent under reduced pressure.The pure product was obtained after purification via flash column chromatography (eluent: $\mathrm{CH}_{2} \mathrm{Cl}_{2}: \mathrm{MeOH} 20: 1 \mathrm{v}: \mathrm{v}$ ) as a white solid (0.036 g, 0.014 mmol, $36 \%$ yield). Mp: $145.7-147.3{ }^{\circ} \mathrm{C} .{ }^{1} \mathrm{H}$ NMR $\left(400 \mathrm{MHz}, \mathrm{CDCl}_{3}\right)$ $\delta$ (ppm): 8.97 (s, 4H, ArNHCS), 8.19 (s, 4H, CSNHCH $\left.{ }_{2}\right), 7.38$ (s, 4H, ArH), 7.05 (s, 4H, ArH), 5.85-5.75 (m, 8H, NHAc, $\left.\mathrm{H}_{3}\right), 5.29$ (d, $\left.4 \mathrm{H}, J_{1,2}=5.6 \mathrm{~Hz}, \mathrm{H}_{1}\right), 5.11\left(\mathrm{t}, 4 \mathrm{H}, J=10.0 \mathrm{~Hz}, \mathrm{H}_{4}\right), 4.97-4.88(\mathrm{~m}$, $\left.4 \mathrm{H}, \mathrm{H}_{2}\right), 4.31\left(\mathrm{dd}, 4 \mathrm{H}, \mathrm{J}_{6 \mathrm{a}, 5}=5.2, J_{6 \mathrm{a}, 6 \mathrm{~b}}=12.2 \mathrm{~Hz}, \mathrm{H}_{6 \mathrm{a}}\right), 4.07-3.93(\mathrm{~m}$, $\left.8 \mathrm{H}, \mathrm{H}_{6 \mathrm{~b}}, \mathrm{OCHHCH} \mathrm{CH}_{2}\right), 3.98\left(\mathrm{~s}, 4 \mathrm{H}, \mathrm{ArCH}_{2} \mathrm{Ar}\right), 3.80\left(\mathrm{br}, 8 \mathrm{H}, \mathrm{H}_{5}\right.$, $\mathrm{CHHNH}), 3.64\left(\mathrm{~s}, 4 \mathrm{H}, \mathrm{ArCH} \mathrm{Hr}_{2} \mathrm{Ar}\right), 3.70-3.50\left(\mathrm{~m}, 8 \mathrm{H}, \mathrm{ArOCH}_{2}\right), 3.46$ (br, $4 \mathrm{H}, \mathrm{OCHHCH}_{2} \mathrm{CH}_{2}$ ), 2.95 (br, $\left.4 \mathrm{H}, \mathrm{CHHNH}\right), 2.48(\mathrm{br}, 4 \mathrm{H}$, $\left.\mathrm{OCH}_{2} \mathrm{CHHCH}_{2}\right), 2.11\left(\mathrm{~s}, 12 \mathrm{H}, \mathrm{CH}_{3} \mathrm{CO}\right), 2.08\left(\mathrm{~s}, 12 \mathrm{H}, \mathrm{CH}_{3} \mathrm{CO}\right)$, $2.006\left(\mathrm{~s}, 12 \mathrm{H}, \mathrm{CH}_{3} \mathrm{CO}\right), 1.997\left(\mathrm{~s}, 12 \mathrm{H}, \mathrm{CH}_{3} \mathrm{CO}\right), 1.69-1.40(\mathrm{~m}, 12 \mathrm{H}$, $\left.\mathrm{OCH}_{2} \mathrm{CH}_{2} \mathrm{CH}_{3}, \mathrm{OCH}_{2} \mathrm{CHHCH}_{2}\right), 0.74(\mathrm{t}, 12 \mathrm{H}, J=6.8 \mathrm{~Hz}$, $\left.\mathrm{CH}_{2} \mathrm{CH}_{3}\right) .{ }^{13} \mathrm{C}\left\{{ }^{1} \mathrm{H}\right\}$ NMR $\left(100 \mathrm{MHz}, \mathrm{CDCl}_{3}\right) \delta(\mathrm{ppm}): 181.9$ (CS), 171.4, 170.6, 170.5, and $169.9\left(3 \times \mathrm{COCH}_{3}, \mathrm{NHCOCH}_{3}\right)$, 153.6 (Ar ipso), 136.5 (Ar ortho), 133.1 (Ar para), 128.6 and 128.4 (Ar meta), $99.9\left(\mathrm{C}_{1}\right), 74.9\left(\mathrm{ArOCH}_{2}\right) ; 72.9$ (C3); 72.3 (C5); 67.7 $\left(\mathrm{OCH}_{2} \mathrm{CH}_{2} \mathrm{CH}_{2}\right), 66.1(\mathrm{C} 4), 62.3(\mathrm{C} 6), 50.9(\mathrm{C} 2), 42.7\left(\mathrm{CH}_{2} \mathrm{NH}\right)$, 38.2 and $36.6\left(\mathrm{ArCH} \mathrm{H}_{2} \mathrm{Ar}\right), 29.4\left(\mathrm{OCH}_{2} \mathrm{CH}_{2} \mathrm{CH}_{2}\right), 23.6\left(\mathrm{COCH}_{3}\right)$, $23.1\left(\mathrm{ArOCH}_{2} \mathrm{CH}_{2}\right), 21.1$ and $20.8\left(\mathrm{COCH}_{3}\right), 8.9\left(\mathrm{CH}_{2} \mathrm{CH}_{3}\right)$. HRMS (ESI-TOF) $m / z:[\mathrm{M}+2 \mathrm{Na}]^{2+}$ calcd for $\mathrm{C}_{112} \mathrm{H}_{156} \mathrm{~N}_{12} \mathrm{O}_{40} \mathrm{~S}_{4} \mathrm{Na}_{2}$ 1241.9622; found 1241.9635 .

Computational Methods. All calculations were carried out using the Gaussian09 program package. ${ }^{14}$ After building the starting geometries as described throughout the manuscript, they were optimized in the framework of the density functional theory at the B3LYP level ${ }^{9,10}$ using the standard 6-31G(d) basis set. The effect of methanol was considered by performing single-point calculations, at the same level as above, on the gas-phase-optimized geometries using a self-consistent reaction field (SCRF) method, based on the polarizable continuum model (PCM). ${ }^{15-17}$

\section{ASSOCIATED CONTENT}

\section{S Supporting Information}

The Supporting Information is available free of charge on the ACS Publications website at DOI: 10.1021/acs.joc.6b01784.

NMR spectra for compounds 1 and 2; electronic energy and Cartesian coordinates of all computed structures (PDF)

\section{AUTHOR INFORMATION}

\section{Corresponding Authors}

*Tel: (+39) 0382987843. Fax: (+39) 0382987323. E-mail: lucio.toma@unipv.it

*Tel: (+39) 0521905458. Fax: (+39) 0521905472. E-mail: francesco.sansone@unipr.it

\section{Notes}

The authors declare no competing financial interest.

\section{ACKNOWLEDGMENTS}

The Italian Ministry of University and Research (PRIN 201011 grant, prot. 2010JMAZML, Italian network for the development of multivalent nanosystems) and the Universities of Pavia and Parma are gratefully acknowledged for financial support. The Centro Interdipartimentale Misure "G. Casnati" of the University of Parma is acknowledged for the NMR and MS facilities.

\section{REFERENCES}

(1) In Calixarenes: An Introduction; Gutsche, C. D., Stoddart, J. F., Eds.; The Royal Society of Chemistry: Cambridge, 2008; p 276.

(2) Sansone, F.; Casnati, A. Chem. Soc. Rev. 2013, 42, 4623-4639.

(3) André, S.; Sansone, F.; Kaltner, H.; Casnati, A.; Kopitz, J.; Gabius, H.-J.; Ungaro, R. ChemBioChem 2008, 9, 1649-1661.

(4) Liu, T. Y.; Gotschlich, E. C.; Jonssen, E. K.; Wysocki, J. R. J. Biol. Chem. 1971, 246, 2849-2858.

(5) Katzenellenbogen, E.; Jennings, H. J. Carbohydr. Res. 1983, 124, $235-245$.

(6) Ohno, N.; Yadomae, T.; Miyazaki, T. Carbohydr. Res. 1980, 80, 297-304.

(7) Legnani, L.; Ronchi, S.; Fallarini, S.; Lombardi, G.; Campo, F.; Panza, L.; Lay, L.; Poletti, L.; Toma, L.; Ronchetti, F.; Compostella, F. Org. Biomol. Chem. 2009, 7, 4428-4436.

(8) Manea, F.; Bindoli, C.; Fallarini, S.; Lombardi, G.; Polito, L.; Lay, L.; Bonomi, R.; Mancin, F.; Scrimin, P. Adv. Mater. 2008, 20, 43484352.

(9) Becke, A. D. J. Chem. Phys. 1993, 98, 5648-5652.

(10) Lee, C.; Yang, W.; Parr, R. G. Phys. Rev. B: Condens. Matter Mater. Phys. 1988, 37, 785-789.

(11) Legnani, L.; Compostella, F.; Sansone, F.; Toma, L. J. Org. Chem. 2015, 80, 7412-7418.

(12) Sansone, F.; Casnati, A.; Chierici, E.; Ungaro, R. Org. Biomol. Chem. 2003, 1, 1802-1809.

(13) The intramolecular hydrogen bonds that stabilize conformers 1A-C in chloroform are broken in a protic polar solvent such as methanol that replaces them with solvent/solute hydrogen bonds. Thus, in methanol unfolded structures should become preferred. Actually, when unfolded structures were optimized in vacuum and their energy recalculated in methanol in single-point calculations, the large preference observed for the 1,3-alternate geometry was lost and the partial cone became preferred over the cone and 1,3-alternate geometries by about 1 and $2 \mathrm{kcal} / \mathrm{mol}$, respectively, in agreement with the signal pattern observed in Figure $1 \mathrm{~b}$ (see also Figure 1S, Supporting Information).

(14) Frisch, M. J.; Trucks, G. W.; Schlegel, H. B.; Scuseria, G. E.; Robb, M. A.; Cheeseman, J. R.; Scalmani, G.; Barone, V.; Mennucci, B.; Petersson, G. A.; Nakatsuji, H.; Caricato, M.; Li, X.; Hratchian, H. P.; Izmaylov, A. F.; Bloino, J.; Zheng, G.; Sonnenberg, J. L.; Hada, M.; Ehara, M.; Toyota, K.; Fukuda, R.; Hasegawa, J.; Ishida, M.; Nakajima, T.; Honda, Y.; Kitao, O.; Nakai, H.; Vreven, T.; Montgomery, J. A., Jr.; Peralta, J. E.; Ogliaro, F.; Bearpark, M.; Heyd, J. J.; Brothers, E.; Kudin, K. N.; Staroverov, V. N.; Keith, T.; Kobayashi, R; Normand, J.; Raghavachari, K.; Rendell, A.; Burant, J. C.; Iyengar, S. S.; Tomasi, J.; Cossi, M.; Rega, N.; Millam, J. M.; Klene, M.; Knox, J. E.; Cross, J. B.; Bakken, V.; Adamo, C.; Jaramillo, J.; Gomperts, R.; Stratmann, R. E.; Yazyev, O.; Austin, A. J.; Cammi, R.; Pomelli, C.; Ochterski, J. W.; Martin, R. L.; Morokuma, K.; Zakrzewski, V. G.; Voth, G. A.; Salvador, P.; Dannenberg, J. J.; Dapprich, S.; Daniels, A. D.; Farkas, O.; Foresman, J. B.; Ortiz, J. V.; Cioslowski, J.; Fox, D. J. Gaussian 09, Revision B.01; Gaussian, Inc.: Wallingford, CT, 2010.

(15) Cancés, E.; Mennucci, B.; Tomasi, J. J. Chem. Phys. 1997, 107, 3032-3042.

(16) Cossi, M.; Barone, V.; Cammi, R.; Tomasi, J. Chem. Phys. Lett. 1996, 255, 327-335. 
(17) Barone, V.; Cossi, M.; Tomasi, J. J. Comput. Chem. 1998, 19, 404-417. 